\title{
Variation in plasma concentrations of oestradiol-17 $\beta$ and their relationship to those of progesterone, 13,14-dihydro-15-keto-prostaglandin F-2 $\alpha$ and oxytocin across pregnancy and at parturition in pony mares*
}

\author{
G. J. Haluska $†$ and W. B. Currie \\ Department of Animal Science, Cornell University, Ithaca, NY 14853-4801, U.S.A.
}

\begin{abstract}
Summary. Concentrations of plasma progesterone were similar to values reported in the literature except that a significant decrease in progesterone during the last day, but before parturition, was detected by systematic, high-intensity blood sampling. Mean concentrations of oestradiol-17 $\beta$ increased sharply and significantly, plateaued for $132.8 \pm 1.5$ days (mean \pm s.e.m., $N=9$ ), then declined sharply in each mare. There was obvious variation between the mares in when these increases and decreases in oestradiol-17 $\beta$ occurred, with the events being related closely to ambient photoperiod conditions rather than to the stage of pregnancy. Concentration of 13,14-dihydro-15keto-prostaglandin F-2 $\alpha$ (PGFM) remained at low levels $(<400 \mathrm{pg} / \mathrm{ml})$ until Day 200 then increased to peak pregnancy levels $(>2000 \mathrm{pg} / \mathrm{ml})$ by Day 300 and remained at this value until parturition. The concentrations of oxytocin remained basal $(<15 \mu \mathrm{U} /$ $\mathrm{ml}$ ) throughout pregnancy and increased only at the beginning of the expulsive stage of labour. There was an increase, although not statistically significant, in the relative concentrations of oestradiol- $17 \beta$ to progesterone beginning 3 days before parturtion, with the highest value of the ratio occurring at fetal delivery. Far more striking were acute changes in PGFM and oxytocin during parturition. Maximal concentrations of PGFM $(\sim 30 \mathrm{ng} / \mathrm{ml})$ and oxytocin $(>200 \mu \mathrm{U} / \mathrm{ml})$ were measured between rupture of the chorioallantois and the completion of delivery. Closely timed samples from one animal showed that oxytocin increased (more than 10 standard deviations of the mean levels during late pregnancy for this animal) before any change in PGFM. In another dystocic mare, both oxytocin and PGFM peaked in the initial stages of delivery but only oxytocin remained elevated until the dystocia was remedied. The results suggest that an abrupt increase in oxytocin secretion precipitates the expulsive phase of parturition in mares.
\end{abstract}

Keywords: oestradiol-17ß; progesterone; PGFM; oxytocin, pregnancy; parturition; mare

\section{Introduction}

The pattern of change in plasma concentrations of oestradiol-17 $\beta$ and progesterone across pregnancy in horses and related equids is atypical of most of the commonly described mammals. Peripheral concentrations of progesterone increase early in pregnancy, peak between Days 60 and 120 , subsequently decline to stable and relatively low levels, and finally increase slightly during the

\footnotetext{
*Reprint requests to Dr W. B. Currie.

†Present address: Oregon Regional Primate Reasearch Center, 505 N.W. 185th Avenue, Beaverton, Oregon 97006, U.S.A.
} 
last 30 days pre partum. It has been reported that plasma concentrations of progesterone decrease only after delivery of the placenta (Holtan et al., 1975a, b; Seamans et al., 1979; Seren et al., 1981; Pope et al., 1987).

In contrast to progesterone which plays the dominant role in most species for maintenance of pregnancy (Csapo, 1956; Goto \& Csapo, 1959; Kuriyama \& Csapo, 1961), oestradiol-17 $\beta$, the most potent of the naturally occurring oestrogens, is important for enhanced and co-ordinated uterine activity during the evolution of labour at term. These steroidal controls have been described as being chronic to distinguish them from regulators such as oxytocin and the prostanoids that exert totally different and acute controls on the myometrium (Currie, 1980). In mares, oestradiol is present in significant concentrations from Day 150, levels peak at Day 240, then gradually decline to parturition (Nett et al., 1973). In contrast, Barnes $e$ t al. (1975) were unable to detect oestradiol$17 \beta$ until 14 days pre partum and they described oestradiol-17 $\beta$ as increasing towards the day of parturition. Neither of these earlier studies used the highly selective and sensitive immunoassays presently available for oestradiol-17 $\beta$.

The present study was undertaken to correlate changes in the most important of the chronically-acting steroidal hormones with the functional behaviour of the myometrium during pregnancy (Haluska et al., 1987b) and at parturition (Haluska et al., 1987a). Special interest in the mare stems from its uniqueness in oestrogens increasing (Nett et al., 1973) and progesterone decreasing (Holtan et al., 1975a, b) at mid-pregnancy. This generates a steroidal environment that typically is observed only near or at parturition in other species. Additionally, because prostaglandins (PGs) are produced in increasing quantities at this time (Barnes et al., 1978; Silver et al., 1979), the mare's uterus exhibits some functional responses to the steroids that also are usually best observed at parturition in other species (Haluska et al., 1987b).

Allen \& Pashen (1981) reported that concentrations of 13,14-dihydro-15-keto-prostaglandin F-2 $\alpha$ (PGFM) in maternal plasma increased pre partum, although Stewart et al. (1984) found no change during the pre-partum period. The horse uterus is atypically responsive to oxytocin in advanced pregnancy and there is widespread clinical use of oxytocin to precipitate fetal delivery (Hillman, 1975). Peripheral oxytocin concentrations measured in 3 pony mares were reported (Allen et al., 1973) to increase during Stage II of labour.

This paper describes changes in plasma concentrations of oestradiol-17ß, progesterone and PGFM across pregnancy in pony mares and provides detailed information on the changes occurring in these hormones and oxytocin in relation to the exact time of parturition. Particular attention is given to the factors likely to modulate secretion of the acute regulators of uterine function.

\section{Materials and Methods}

Animals. Nine pony mares of mixed breeding were housed in tie-stalls and were fed hay at 08:00 h and hay supplemented with concentrates at 18:00 h; water was available ad libitum. Myometrial electromyographic electrodes were surgically implanted in 5 of the mares (Haluska et al., 1987a, b) to monitor uterine activity (Table 1). Mares not subjected to surgery were turned out to pasture from 10:00 to 15:00 h each day. The end of the normal breeding season was extended by using supplemental lighting (16 h light each day from $200-\mathrm{W}$ incandescent bulbs providing $13-43$ foot-candles at eye level) to ambient light which was not quantified but was generous; the lighting regimen began before first mating (August 1981) and continued until all mares had foaled (January 1983). All of the mares continued to cycle until they were mated. To facilitate intensive monitoring and sampling near parturition, groups of mares were mated between September 1981 and February 1982. Every mare conceived during the oestrus in which she was mated.

Mares were mated to a pony stallion and pregnancies were dated from the last day of standing oestrus (Day 0 ). Animals were treated prophylactically against abortion due to Equine Herpesvirus I with 2 ml Pneumabort K (Fort Dodge Labs, Inc., Fort Dodge, IA, U.S.A.) during the 5th, 7 th and 9 th months of pregnancy. Mare 205 aborted on Day 285 and necropsy indicated the abortion to be secondary to bacteraemia induced by Staphylococcus aureus. Samples were collected from a replacement (Mare 101) during the parturient period to maintain a consistent number of animals.

Blood sampling. Jugular blood was collected using heparinized Vacutainers every 3rd day during pregnancy. Catheters were placed percutaneously into the jugulars of 7 of the 9 mares 2 weeks before expected parturition; 2 mares delivered spontaneously at term but before catheters were placed. Samples were collected from the catheters at 
4-h intervals until parturition seemed imminent, at 1-h intervals until delivery began and then as frequently as possible $(\sim 1 / \mathrm{min})$ until delivery was completed then every $10 \mathrm{~min}$ until the placenta was delivered.

Radioimmunoassays. All plasma samples were assayed for progesterone, oestradiol-17 $\beta$, PGFM and oxytocin, using methods described in detail by Currie et al. (1988). The only significant cross-reactivity of the antiserum used to measure progesterone was to $5 \beta$-dihydroprogesterone (11.6\%), but petroleum ether (BP 40-60) was used to minimize extraction of the more polar metabolites from plasma. The coefficients of variation between and within assays were 16.0 and $7.6 \%$ respectively; samples from individual mares were measured on a within-assay basis. Oestradiol-17 $\beta$ was determined in selected samples using antiserum GDN No. 244, after extraction and chromatographic separation. Oestradiol-17 $\alpha$ and $-17 \beta$ were isolated from other oestrogens before quantification so the only relevant crossreactivity of the antiserum is to oestradiol-17a $(0.002 \%)$. The coefficients of variation between and within oestradiol173 assays were 12.2 and $7.6 \%$ respectively; all samples from a given mare were included in a single assay. PGFM and oxytocin were measured exactly as described by Currie et al. (1988). The coefficients of variation of the remaining assays were 10.7 and $9 \cdot 2 \%$ (between and within, respectively) for PGFM, and 14.3 and $6.6 \%$ for oxytocin.

During early and late pregnancy, oestradiol-17 $\beta$, PGFM and oxytocin were determined at 9-day intervals and between Days 198 and 246, at 6-day intervals. During the pre-partum period, daily samples collected at $08: 00 \mathrm{~h}$ were assayed, as were all samples collected during parturition.

Statistics. Variation in plasma concentrations of the steroids was assessed by analyses of variance examining differences between days of pregnancy (or pre partum) and between animals. Linear contrasts were made using Scheffe's adaptation to determine significance of differences between individual means.

\section{Results}

\section{Progesterone}

Mean concentrations of circulating progesterone (Fig. 1) at the beginning of pregnancy were $\sim 10 \mathrm{ng} / \mathrm{ml}$, similar to reported values during dioestrus (Ginther, 1979), and they decreased slightly to $7.6 \mathrm{ng} / \mathrm{ml}$ on Day 24. Progesterone concentrations again increased to $30.8 \mathrm{ng} / \mathrm{ml}$ by Day 72 , remained elevated $(32.5 \mathrm{ng} / \mathrm{ml})$ until Day 126 , declined gradually to Day 153 and then fell rapidly to $\sim 4-5 \mathrm{ng} / \mathrm{ml}$. Variation between the mares was obvious; in Mares 203 and 46, progesterone never exceeded $11 \cdot 0 \mathrm{ng} / \mathrm{ml}$ while peak concentrations of $25 \cdot 1-78 \cdot 7 \mathrm{ng} / \mathrm{ml}$ were measured in the remainder. A slight increase from $\sim 4-5 \mathrm{ng} / \mathrm{ml}$ to $\sim 7-8 \mathrm{ng} / \mathrm{ml}$ was detected during the last 2 weeks pre partum.

Changes in the mean concentrations of progesterone during the last 3 days before parturition are shown in Fig. 2: values decreased from $7.0 \pm 1.2 \mathrm{ng} / \mathrm{ml}$ at $28 \mathrm{~h}$ pre partum to $4.4 \pm 0.9 \mathrm{ng} / \mathrm{ml}$ at $16 \mathrm{~h}$ pre partum and finally decreased to $3.5 \pm 0.3 \mathrm{ng} / \mathrm{ml}$ at parturition. The decrease in progesterone from pre-partum to parturient levels was significant $(P<0.00 \mathrm{I})$.

\section{Oestradiol $-17 \beta$}

Mean peripheral concentrations of oestradiol-17 $\beta$ (Fig. 1) increased slowly above basal values $(<10 \mathrm{pg} / \mathrm{ml})$ after Day 108 and were markedly increased, beginning on Day 153, to reach $230 \cdot 3 \pm 71 \cdot 4 \mathrm{pg} / \mathrm{ml}$ on Day 198 . Concentrations then plateaued before declining sharply after Day 279 when mean values were $244.0 \pm 53.7 \mathrm{pg} / \mathrm{ml}$. Variation between the individual mares was quite evident, as detailed in Table 1. The day of pregnancy at the beginning and end of the plateau period varied widely, but the duration of the plateau and the calendar dates of the changes were very consistent. The plateau period was timed from the abrupt increase (documented in Table 1) and averaged 132.8 \pm 1.5 days for the 9 mares. All increases occurred during a 7-day period between 13 and 20 April 1982 and the decreases occurred over a 5-day period between 24 and 29 August 1982, without regard for the day of pregnancy. Meteorological data collected in Ithaca, NY, showed a range of $13 \cdot 2-13.6 \mathrm{~h}$ daylight for the April dates and 13.5-13.2 h daylight for the August dates. There was no uniformity in the duration of the interval (2-101 days) from the decrease in plasma oestradiol-17 $\beta$ until parturition (Table 1). There was no statistical difference in mean concentrations for given stages of pregnancy between mares carrying male $(\mathrm{N}=3)$ or female $(\mathrm{N}=5)$ fetuses; data from Mare 205 were excluded from this comparison.

There was no statistically significant change in the mean plasma concentrations of oestradiol$17 \beta$ near parturition but slight increases in oestradiol-17 $\beta$ were evident in the serial samples for 


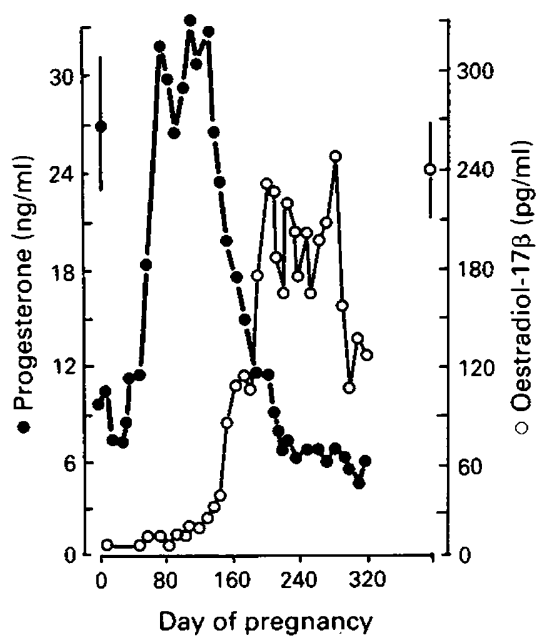

Fig. 1. Average plasma progesterone $(--)$ and oestradiol-17ß $(O-O)$ concentrations during pregnancy, but excluding the parturient period, in 8 pony mares. The bars next to the axes indicate standard errors of the means from the analyses of variance for the 2 sets of data.

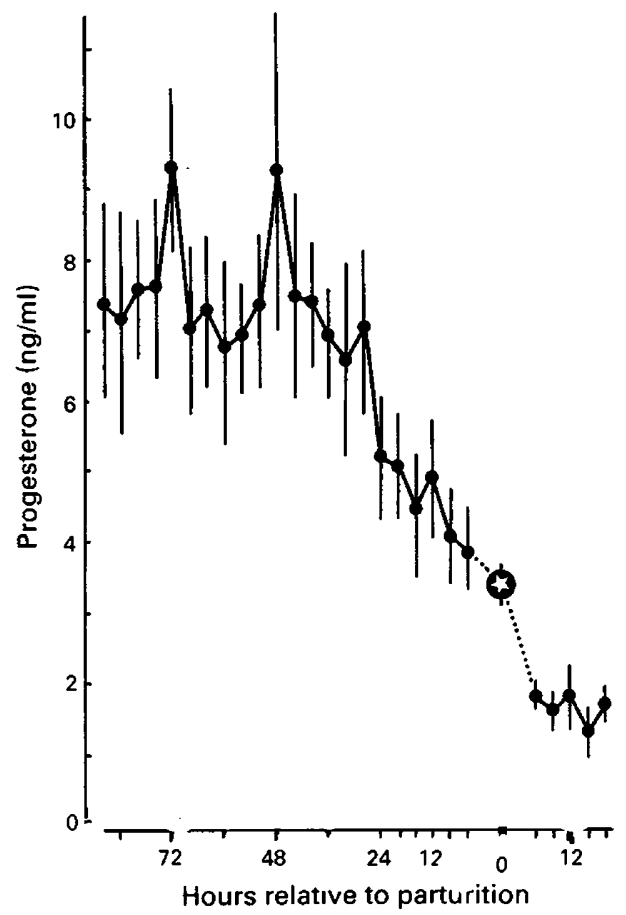

Fig. 2. Peripheral plasma concentrations of progesterone during the last $88 \mathrm{~h}$ before parturition in pony mares (mean \pm s.e.m., $N=6$ ). The star indicates samples taken at the completion of delivery of the foals. 
Table 1. Changes in plasma concentrations of oestradiol-17 $\beta\left(E_{2} \beta\right)$ for the 9 mares (including the beginning of pregnancy, the days of pregnancy (and dates) when the marked increase and decrease in $E_{2} \beta$ occurred (see text for more detail), concentrations in the previous or next sample assayed, duration of the

phase of elevated concentrations of $\mathrm{E}_{2} \beta$, the date of parturition, and the duration of pregnancy)

\begin{tabular}{|c|c|c|c|c|c|c|c|c|c|c|}
\hline \multirow[b]{2}{*}{ Mare } & \multirow[b]{2}{*}{$\begin{array}{l}\text { Day } 0 \text { of } \\
\text { pregnancy }\end{array}$} & \multicolumn{3}{|c|}{ Increase } & \multicolumn{3}{|c|}{ Decrease } & \multirow{2}{*}{$\begin{array}{c}\text { Duration } \\
\text { of } \\
\text { plateau } \\
\text { (days) }\end{array}$} & \multirow[b]{2}{*}{ Parturition } & \multirow{2}{*}{$\begin{array}{l}\text { Duration } \\
\text { of } \\
\text { pregnancy } \\
\text { (days) }\end{array}$} \\
\hline & & Day & $\begin{array}{l}\text { Date } \\
\text { (Apr.) }\end{array}$ & $\begin{array}{c}\mathrm{E}_{2} \beta \\
(\mathrm{pg} / \mathrm{ml})\end{array}$ & Day & $\begin{array}{l}\text { Date } \\
\text { (Aug.) }\end{array}$ & $\underset{(\mathrm{pg} / \mathrm{ml})}{\mathrm{E}_{2} \beta}$ & & & \\
\hline $205^{*}$ & 16 Feb. 1982 & $\begin{array}{l}48 \\
57\end{array}$ & $\begin{array}{r}5 \\
14\end{array}$ & $\begin{array}{r}3 \cdot 1 \\
104 \cdot 9\end{array}$ & $\begin{array}{l}177 \\
189\end{array}$ & $\begin{array}{l}12 \\
24\end{array}$ & $\begin{array}{r}417.4 \\
25.9\end{array}$ & 132 & 28 Nov. 1982 & $285 \dagger$ \\
\hline $203^{*}$ & 7 Jan. 1982 & $\begin{array}{l}90 \\
99\end{array}$ & $\begin{array}{r}7 \\
16\end{array}$ & $\begin{array}{r}7 \cdot 6 \\
258 \cdot 7\end{array}$ & $\begin{array}{l}228 \\
231\end{array}$ & $\begin{array}{l}23 \\
26\end{array}$ & $\begin{array}{r}222 \cdot 8 \\
39 \cdot 1\end{array}$ & 132 & 5 Dec. 1982 & 332 \\
\hline 195 & 12 Nov. 1981 & $\begin{array}{l}144 \\
153\end{array}$ & $\begin{array}{r}5 \\
14\end{array}$ & $\begin{array}{r}18 \cdot 3 \\
124 \cdot 4\end{array}$ & $\begin{array}{l}279 \\
285\end{array}$ & $\begin{array}{l}18 \\
24\end{array}$ & $\begin{array}{r}463 \cdot 6 \\
38 \cdot 4\end{array}$ & 132 & 9 Oct. 1982 & 331 \\
\hline 198 & 12 Nov. 1981 & $\begin{array}{l}150 \\
153\end{array}$ & $\begin{array}{l}11 \\
14\end{array}$ & $\begin{array}{r}29 \cdot 6 \\
169 \cdot 3\end{array}$ & $\begin{array}{l}279 \\
291\end{array}$ & $\begin{array}{l}18 \\
30\end{array}$ & $\begin{array}{r}346 \cdot 9 \\
24 \cdot 6\end{array}$ & 138 & 27 Sep. 1982 & 319 \\
\hline $196^{*}$ & 6 Nov. 1981 & $\begin{array}{l}153 \\
162\end{array}$ & $\begin{array}{r}8 \\
17\end{array}$ & $\begin{array}{r}12 \cdot 7 \\
153 \cdot 6\end{array}$ & $\begin{array}{l}291 \\
297\end{array}$ & $\begin{array}{l}24 \\
30\end{array}$ & $\begin{array}{r}100 \cdot 1 \\
40 \cdot 3\end{array}$ & 135 & 4 Oct. 1982 & 332 \\
\hline $100^{*}$ & 9 Nov. 1981 & $\begin{array}{l}153 \\
162\end{array}$ & $\begin{array}{l}11 \\
20\end{array}$ & $\begin{array}{r}23 \cdot 1 \\
246 \cdot 1\end{array}$ & $\begin{array}{l}285 \\
288\end{array}$ & $\begin{array}{l}24 \\
27\end{array}$ & $\begin{array}{r}294 \cdot 8 \\
37 \cdot 4\end{array}$ & 126 & 6 Oct. 1982 & 331 \\
\hline 46 & 6 Oct. 1981 & $\begin{array}{l}180 \\
189\end{array}$ & $\begin{array}{r}4 \\
13\end{array}$ & $\begin{array}{l}23 \cdot 5 \\
74 \cdot 3\end{array}$ & $\begin{array}{l}324 \\
327\end{array}$ & $\begin{array}{l}26 \\
29\end{array}$ & $\begin{array}{r}245 \cdot 5 \\
38 \cdot 2\end{array}$ & 138 & 31 Aug. 1982 & 329 \\
\hline $137^{*}$ & 12 Oct. 1981 & $\begin{array}{l}177 \\
189\end{array}$ & $\begin{array}{r}7 \\
19\end{array}$ & $\begin{array}{r}26 \cdot 0 \\
415 \cdot 4\end{array}$ & $\begin{array}{l}315 \\
321\end{array}$ & $\begin{array}{l}23 \\
29\end{array}$ & $\begin{array}{r}307 \cdot 4 \\
30 \cdot 4\end{array}$ & 132 & 7 Sep. 1982 & 330 \\
\hline 204 & 30 Sep. 1981 & $\begin{array}{l}189 \\
198\end{array}$ & $\begin{array}{r}7 \\
16\end{array}$ & $\begin{array}{r}34 \cdot 5 \\
718 \cdot 2\end{array}$ & $\begin{array}{l}327 \\
333\end{array}$ & $\begin{array}{l}23 \\
29\end{array}$ & $\begin{array}{r}228 \cdot 0 \\
20 \cdot 4\end{array}$ & 135 & 1 Sep. 1982 & 336 \\
\hline
\end{tabular}

*Mares surgically prepared for electromyography.

†Aborted.

each mare; this increase occurred at 4 days ( 1 mare), 3 days ( 3 mares) or 2 days ( 2 mares) before parturition. While the mean ratio of oestradiol-17 $\beta$ relative to progesterone doubled over the last 4 days, analysis of variance of the ratio estimates, which varied substantially between mares, showed no significant overall change.

\section{3,14-Dihydro-15-keto-prostaglandin F-2a}

Basal plasma concentrations of PGFM for the 8 mares were $\sim 0.4 \mathrm{ng} / \mathrm{ml}$ until Day 200 then increased to $0.9 \pm 0.1 \mathrm{ng} / \mathrm{ml}$ by Day 260 (Fig. 3). A more abrupt increase followed to $1.9 \pm 0.9 \mathrm{ng} /$ $\mathrm{ml}$ (range $0.5-7.8$ ) by Day 270 then to $3.4 \pm 1.4 \mathrm{ng} / \mathrm{ml}$ (range $0.9-12.6$ ) by Day 300 . The values at Day 270 and later were significantly $(P<0.001)$ greater than those earlier in pregnancy. During the last 15 days pre partum, concentrations in the $08: 00 \mathrm{~h}$ samples varied among the mares but the average concentration of $2.5 \mathrm{ng} / \mathrm{ml}$ did not change in any consistent fashion on a day-by-day basis (see insert, Fig. 3). PGFM concentrations then increased suddenly just before rupture of the chorioallantoic membranes.

The great magnitude of this final increase is illustrated in Fig. 4 for Mare 101, from which a comprehensive set of samples was obtained. There was no systematic change in PGFM until the major increase attending rupture of the membranes. The sample collected 8 min before membrane rupture contained $2 \cdot 3 \mathrm{ng} / \mathrm{ml}$ and was no different from the levels measured throughout the preceding 2 weeks. Concentrations increased to a peak of $29 \cdot 1 \mathrm{ng} / \mathrm{ml}$, just $4 \mathrm{~min}$ before the fluids were released, they decreased transiently then increased again with the delivery of the foal. The group 


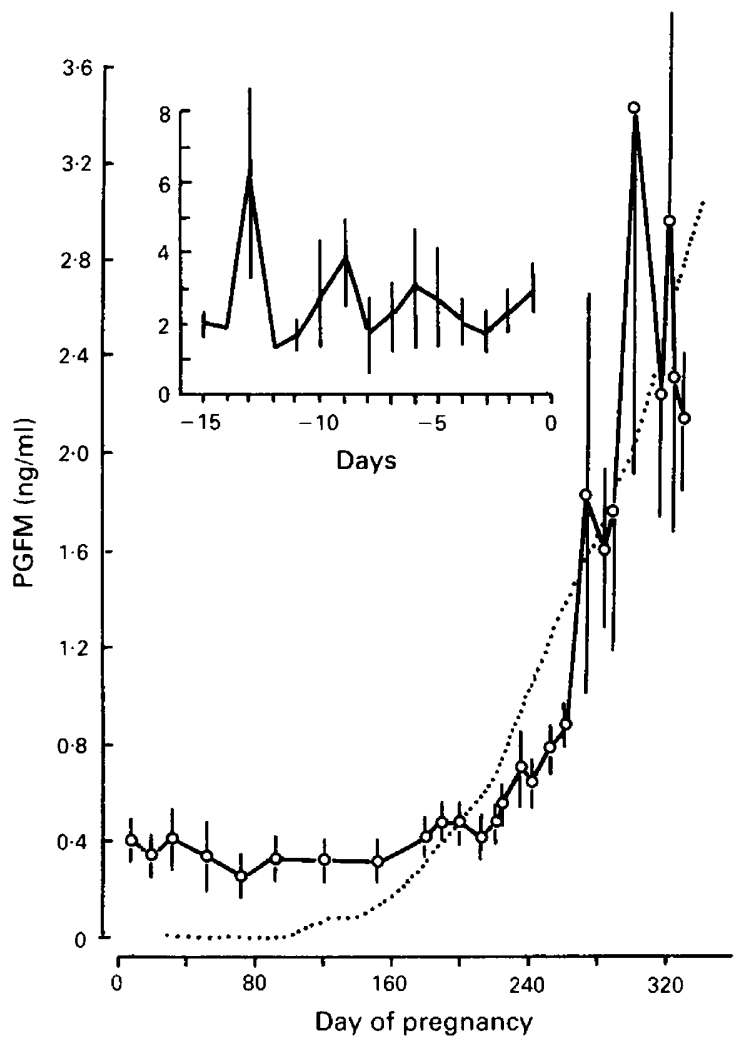

Fig. 3. Plasma concentrations of 13,14-dihydro-15-keto-prostaglandin F-2 $\alpha$ (PGFM) in pony mares during pregnancy $(O-O$, means \pm s.e.m., $N=8$ ). Superimposed on the figure is the growth curve ( $\cdots$ ) for the horse fetus (after Bergin et al., 1967). The insert shows PGFM values plotted for the last 16 days before parturition for 6 mares.

data on changes in PGFM at various times during parturition are shown in Fig. 5(a). Peak concentrations were measured when the head of the fetus was visible at the labia. At the completion of fetal delivery, values ranged from 17.5 to $92.3 \mathrm{ng} / \mathrm{ml}$ then declined steadily thereafter. The levels were in the pre-delivery range within $1.5 \mathrm{~h}$ post partum.

The time from rupture of the chorioallantois to completion of fetal delivery ranged from 3 to $13 \mathrm{~min}$ and all mares except one delivered the placenta within $30 \mathrm{~min}$; Mare 204 retained the placenta for $120 \mathrm{~min}$.

\section{Oxytocin}

Oxytocin remained at basal concentrations $(<15 \mu \mathrm{U} / \mathrm{ml})$ throughout pregnancy and increased above this level only just before fetal delivery. There was wide variation between the mares in the peak concentration measured between rupture of the chorioallantois and fetal delivery (range 69.6-2882.2 $\mu \mathrm{U} / \mathrm{ml}$ ). Mean concentrations peaked when the head of the fetus was visible at the labia (Fig. 5b) but the peak in individual mares occurred at slightly different times. However, in all mares the interval between the specific events in parturition varied by only a few minutes. In contrast to PGFM, concentrations of oxytocin remained elevated above basal values for 2-4 h post partum.

The most complete set of samples came from Mare 101 (Fig. 4). The last routinely collected sample (at $-44 \mathrm{~min}$ ) contained $4.6 \mu \mathrm{U} / \mathrm{ml}$, a value that was within the range of all measurements at earlier stages of pregnancy from this mare. An 8 -fold increase to $39.4 \mu \mathrm{U} / \mathrm{ml}$ occurred by $11 \mathrm{~min}$ 
(a)
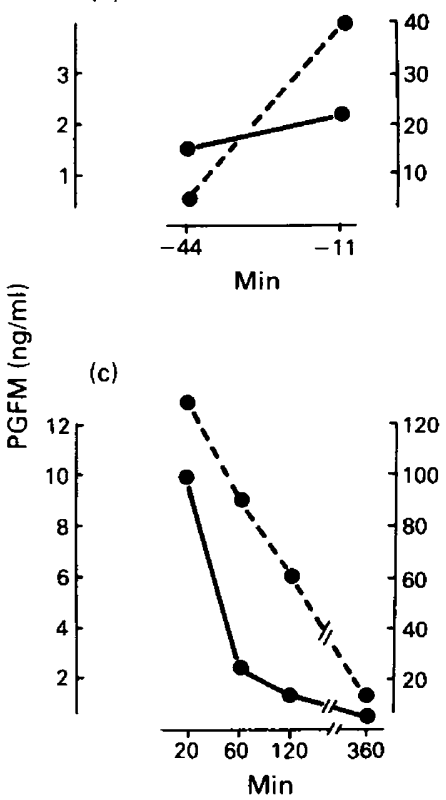

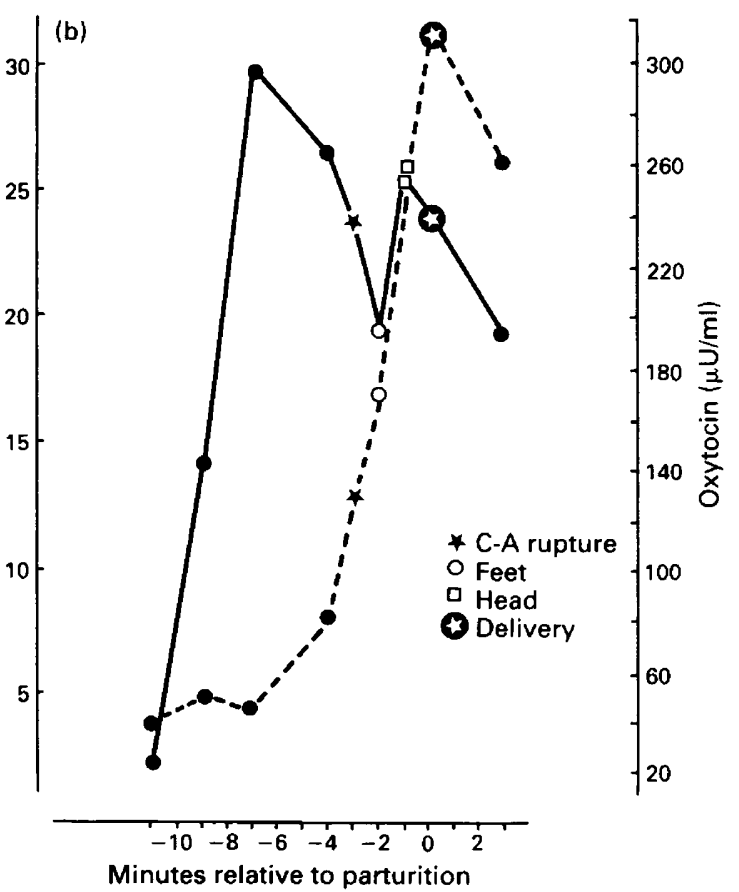

Fig. 4. Plasma concentrations of PGFM (- $)$ and oxytocin (-- ) for Mare 101: (a) before delivery; values are measured concentrations for each hormone; (b) delivery; major events are indicated; (c) after delivery.

before delivery, equivalent to 10 standard deviations above the mean of 20 samples collected on the preceding 10 days. Oxytocin concentrations were increased for at least $2 \mathrm{~min}$ before any increase in PGFM was detected, remained elevated at $40-50 \mu \mathrm{U} / \mathrm{ml}$ for $7 \mathrm{~min}$, and then increased to $255 \mu \mathrm{U} / \mathrm{ml}$ at delivery of the head, and $318 \mu \mathrm{U} / \mathrm{ml}$ at the completion of fetal delivery. Concentrations of oxytocin remained elevated until the placenta was delivered and then slowly declined.

\section{Discussion}

Three novel phenomena are described in this paper: (1) a significant pre-partum decrease in plasma concentrations of progesterone, evident over the $24 \mathrm{~h}$ preceding parturition, was demonstrated by use of reasonably intensive blood sampling; (2) a remarkably consistent pattern of change in plasma concentrations of oestradiol-17 $\beta$, establishing high plateau concentrations in excess of $200 \mathrm{pg} / \mathrm{ml}$ for 133 days, occurred without regard for the stage of pregnancy, but corresponded precisely with the 4 summer months when ambient photoperiod is in excess of $13.2 \mathrm{~h}$ daily at the Ithaca, NY, latitude; (3) a sudden and massive release of oxytocin occurred just minutes before presentation and rupture of the chorioallantois, and this was followed rapidly by delivery of the fetus.

With the exception of the significant pre-partum decline in plasma progesterone, the profile of this hormone across pregnancy was similar to those described by others (Holtan et al., 1975a; Seren et al., 1981). Our measurements are of a similar magnitude to those described by Seamans $e t$ al. (1979) but while Seamans et al. (1979) found a decrease in the levels of $5 \alpha$-pregnanes during the $16 \mathrm{~h}$ before parturition, no such change was noted for progesterone. The antiserum used in our study cross-reacts $<2 \%$ with $5 \alpha$-dihydroprogesterone and, as noted earlier, petroleum ether does not 

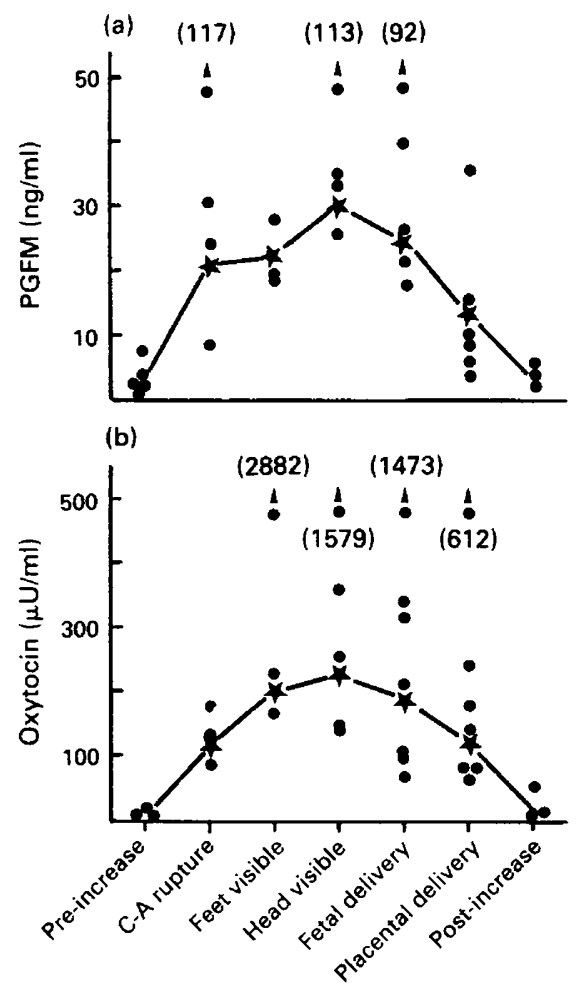

Fig. 5. Concentrations of PGFM (a) and oxytocin (b) in pony mares $(N=9)$ related to the major events of parturition; individual data $(\Theta)$ and means $(\star)$ are indicated. For each hormone there was one mare that had extraordinarily high concentrations; these outlier values are shown in parentheses and were excluded when computing the means. Pre-increase signifies the last sample collected, at a variable time, before the increases attending rupture of the chorioallantois (C-A). Post-increase signifies the first sample obtained, at various times up to $1.5 \mathrm{~h}$ after delivery of the placenta, when concentrations returned to the range of values measured before parturition.

efficiently extract the reduced metabolite. Since our measurements of progesterone are quite comparable to those of Seamans et al. (1979) except for the pre-partum decrease, it is unlikely that the decrease that we describe could be due to $5 \alpha$-dihydroprogesterone. Earlier reports on progesterone concentrations were based on sampling every 4 days (Holtan et al., 1975a, b), once daily (Seren et al., 1981) and twice daily (Seamans et al., 1979), but Pope et al. (1987) sampled mares every $30 \mathrm{~min}$ and described a decline in progesterone that was significant only after delivery. However, our mares were also monitored continuously and fetal delivery was timed precisely; progesterone concentrations at parturition were determined from blood samples collected as the hind legs of the fetus passed through the vulva.

Our results for concentrations of oestradiol-17 $\beta$ in mares differ in many respects from those existing in the literature. Barnes et al. (1975) failed to detect oestradiol-17 $\beta$ before 14 days pre partum in samples collected during the last 7 weeks of pregnancy. Nett et al. (1973) found peak concentrations of $64-119 \mathrm{pg} / \mathrm{ml}$ in pregnant horse mares while our values from pony mares were higher, ranging from 251 to $718 \mathrm{pg} / \mathrm{ml}$. We are unaware of other studies that adequately document oestradiol- $17 \beta$ changes across pregnancy in mares. Our assay uses chromatographic isolation of the oestradiol fraction and an antiserum that is 50000 -fold more selective for oestradiol- $17 \beta$ than the $\alpha$-epimer; the B-ring unsaturated oestrogens are not measured. With so little information available 
for the various members of the horse family, we cannot exclude the possibility that differences between our work and that of Nett et al. (1973) stem from genuine differences between ponies and horses.

The pattern of change in plasma oestradiol described here is also in contrast to the description for horse mares. Nett et al. (1973) found a peak in oestradiol at Day 240 followed by a decrease to $\sim 30-40 \mathrm{pg} / \mathrm{ml}$. Instead of any defined peak, we have found a period of constantly elevated oestradiol- $17 \beta$ concentrations that related closely to time of the year. Concentrations of oestradiol$17 \beta$ increased abruptly in all mares during a 7-day period in the spring when daylight averaged 13.4 $\mathrm{h}$ and when the mares were 57-189 days after mating. After a period of $133 \pm 1.2$ days, oestradiol-17 $\beta$ values declined abruptly during a 5-day period in the late summer when daylight again averaged $13.4 \mathrm{~h}$. These findings are especially interesting because oestrogen production in pregnant equids involves shuttling of precursor androgens from the fetal gonad to the placenta, and the fetal gonad is grossly enlarged and active over defined stages of gestation (Cole et al., 1933). Maternal oestrogens fall precipitously after fetal gonadectomy (Pashen \& Allen, 1979b) and so a feto-placental unit for oestrogen synthesis appears to be well established for the mare. At present we have no explanation of how season could influence the operation of this feto-placental unit.

It is appreciated that the preceding findings are serendipitous because of the strategy used for mating the mares beyond the normal breeding season, which coincidentally also spans the period April to August at this location. Without separating the normal confounding of season of the year with stage of pregnancy, the observations presented here would have been disguised. Seasonality is known to affect other aspects of pregnancy, for example its duration (Howell \& Rollins, 1951; Ropiha et al., 1969), in mares. Other oestrogens, especially the B-ring unsaturated and conjugated steroids that are quantitatively important in mares, were not measured in this study. It would be of interest to examine whether changes in these hormones also relate to season rather than stage of pregnancy.

The low peripheral concentrations measured for PGFM $(<400 \mathrm{pg} / \mathrm{ml})$ during early pregnancy and an increase after Day 200 corroborate the results of Barnes et al. (1978). Oestradiol-17 is stimulatory for PG synthesis in the rat (Ham et al., 1975) but not in the presence of progesterone. In the present study, PGFM values increased after Day 200 of pregnancy despite 5 of the 9 mares displaying declining concentrations of oestradiol- $17 \beta$ and so factors other than the oestradiol-17 $\beta$ to progesterone ratio seem to contribute to the control of PG synthesis. One possibilty is distension of the uterus which promotes uterine production of PGs (Csapo, 1977). The growing conceptus distends, and potentially stretches the uterine wall (Currie, 1979), and the growth curve of the equine fetus (adapted from Bergin et al., 1967), overlaid on the PGFM values in Fig. 3 indicates a similarity in changes in PGFM and fetal growth.

The sustained increase in PGFM concentrations, before the more dramatic events of parturition, occurs when relaxin is secreted in substantial quantities (Stewart \& Stabenfeldt, 1981) and, during the last few weeks, when progesterone values increase (Holtan et al., 1975b). Relaxin and progesterone both serve to maintain distensibility of the uterus (Currie, 1979) and influence excitability and reactivity of the myometrium. The potential stimulatory effect of PGs on the uterus are indeed offset in some way because these mares showed the least amount of electromyographic activity during this second half of pregnancy (Haluska et al., 1987b).

The PGFM values obtained here increased to in excess of $2 \mathrm{ng} / \mathrm{ml}$ about 30 days before parturition then plateaued until labour was quite advanced. This observation contrasts with the report of Allen \& Pashen (1981) who found levels to increase to $2-3 \mathrm{ng} / \mathrm{ml}$ only during the last $7-10$ days, but our finding agrees with Stewart et al. (1984) who found no change over the last 11 days. All of these studies found the dramatic increase in PGFM during parturition that we describe in detail.

We found no consistent interval between the decrease in oestradiol-17 $\beta$ concentrations and parturition (Table 1) which argues against the suggestions (Nett et al., 1973; Cox, 1975; Barnes et al., 1975) that a decline in circulating oestrogens serves to trigger the onset of parturition. The roles of oestrogens in equine pregnancy can be deduced from the study of Pashen \& Allen $(1979 a, b)$. Elimination of all oestrogens from pregnant mares by fetal gonadectomy was of 
consequence only for the growth of the fetus and the duration and forcefulness of labour, which nevertheless still occurred at expected term. As oestrogens are believed to play an important role in the mechanism of labour, there is little argument in favour of oestrogen withdrawal playing a role in timing parturition.

The concentrations of oestradiol- $17 \beta$ remained relatively stable before parturition but the acute pre-partum decrease in progesterone results in an approximate doubling of the relative amounts of oestradiol-17 $\beta$ and progesterone which may provide appropriate conditions for the spontaneous evolution of labour. Such a change could be expected to induce myometrial receptors for oxytocin (Alexandrova \& Soloff, 1980) and relaxin (Mercado-Simmen et al., 1982), to stimulate prostanoid production (Ham et al., 1975; Pashen \& Allen, 1979b), to favour gap-junction formation between myometrial cells (Garfield et al., 1978, 1980) and to modify the population of steroid receptors in the myometrium (Quirk \& Currie, 1984).

The pattern of secretion of oestradiol- $17 \beta$ and progesterone across pregnancy, and the functional consequences in terms of appreciable labour-like uterine activity in mid-pregnancy (Haluska et al., $1987 \mathrm{~b}$ ), are atypical of most animals. However, the findings of a pre-partum reduction in plasma progesterone and the tendency for an increase in the relative concentrations of oestradiol-17 $\beta$ to progesterone indicate that the mare is really not so different from other mammals at parturition. Accompanying these steroidal changes in preparation for parturition, the mare appears to have developed extraordinary control over the events leading to labour and delivery, as demonstrated by an ability to control transiently uterine activity. Haluska et al. (1987a) describe an extended period of increased uterine activity, considered to be Stage I of parturition, and then found a marked decrease in electromyographic activity for $2-4 \mathrm{~h}$ before the sudden onset of the expulsive phase (Stage II of parturition). This complex approach to parturition has not been described for any other species. Stage II of labour would appear to be precipitated by the actions of agonists that acutely regulate myometrial activity; obvious candidates for this role are PGs and oxytocin. In most species, these agents are powerful agonists at term, when uterine sensitivity is enhanced by changes in their receptors and opportunity exists for each to reinforce production or secretion of the other (Flint et al., 1975; Mitchell et al., 1975). Oxytocin is quite efficacious in inducing fetal delivery when administered to near-term mares (Hillman, 1975). Stewart et al. (1984) found increased PGFM concentrations within $3 \mathrm{~min}$ of oxytocin injection used for this purpose.

Because accurate prediction of impending delivery of the foal is not possible, the sampling of most mares was less optimal than that for the animal shown in Fig. 4. Overall, the times when concentrations of oxytocin and PGFM abruptly increased during the few minutes before delivery were so similar that temporal separation was not possible. The detailed description through parturition of changes in both PGFM and oxytocin (Fig. 5) is consistent with the events described during induced parturition (Stewart et al., 1984). It would seem, therefore, that sudden enhanced secretion of oxytocin may trigger the onset of Stage II of labour.

Oxytocin secretion, as part of the genital or the milk ejecting reflex, is subject to central facilitation and/or inhibition. For example, stress significantly decreases oxytocin secretion in rhesus monkeys (Kalin et al., 1985). It is likely that these higher influences are mediated by noradrenergic neurones of limbic origin that are distributed to the supraoptic and paraventricular nuclei (Matzke \& Foltz, 1983; Carpenter, 1972; Bennett \& Whitehead, 1983). Such a pathway could permit oxytocin secretion to occur when emotional or stress-free conditions are favourable for the action of the hormone. As mares are well recognized for having an atypically high degree of maternal control over the expulsive phase of parturition, it is possible that this control is exerted on the delivery-triggering release of oxytocin.

This work was done in partial fulfilment of the requirements for the Ph.D. degree in the Field of Animal Science at Cornell University (G.J.H.). The work was supported in part by a Grant-in-Aid from Sigma Xi, The Scientific Research Society, to G.J.H. We thank Frank Michel and Carolyn Prouty for technical assistance. 


\section{References}

Alexandrova, M. \& Soloff, M.S. (1980) Oxytocin receptors and parturition. I. Control of oxytocin receptor concentrations in the rat myometrium at term. Endocrinology 106, 730-735.

Allen, W.R. \& Pashen, R.L. (1981) The role of prostaglandins during parturition in the mare. Acta vet. scand., Suppl. 77, 279-298.

Allen, W.R., Chard, T. \& Forsling, M.L. (1973) Peripheral plasma levels of oxytocin and vasopressin in the mare during parturition.J. Endocr. 57, 175-176.

Barnes, R.J., Nathanielsz, P.W., Rossdale, P.D., Comline, R.S. \& Silver, M. (1975) Plasma progestagens and oestrogens in fetus and mother in late pregnancy. $J$. Reprod. Fert., Suppl. 23, 617-623.

Barnes, R.J., Comline, R.S., Jeffcott, L.B., Mitchell, M.D., Rossdale, P.D. \& Silver, M. (1978) Foetal and maternal plasma concentrations of 13,14-dihydro-15oxo-prostaglandin $F$ in the mare during late pregnancy and at parturition. $J$. Endocr. 78, 201-215.

Bennett, G.W. \& Whitehead, S.A. (1983) Mammalian Neuroendocrinology, ch. 3, p. 81. Oxford University Press, London.

Bergin, W.C., Gier, H.T., Frey, R.A. \& Marion, G.B. (1967) Developmental horizons and measurements useful for age determination of equine embryos and fetuses. Am. Assoc. Equine Pract., Proc. 13th Ann. Mtg, New Orleans. pp. 179-196.

Carpenter, M.B. (1972) Core Text of Neuroanatomy, ch. 9, p. 170. Williams and Williams Company, Baltimore

Cole, H.H., Hart, G.H., Lyons, W.R. \& Catchpole, H.R. (1933) The development and hormonal content of fetal horse gonads. Anat Rec. 56, 275-293.

Cox, J.E. (1975) Oestrone and equilin in the plasma of the pregnant mare. J. Reprod. Fert., Suppl. 23, $463-468$.

Csapo, A. (1956) Progesterone block. Am. J. Anat. 98, 273-291.

Csapo, A.I (1977) The effect of ovariectomy and stretch on the regulatory profile and activity of the uterus. Prostaglandins 13, 965-973.

Currie, W.B. (1979) Uterine excitability and distensibility influenced by treatment in vitro with progesterone. Anim. Reprod. Sci. 2, 225-238.

Currie, W.B. (1980) Physiology of uterine activity. Clin. Obstet. Gynecol. 23, 33-49.

Currie, W.B. Gorewit, R.C. \& Michel, F.J. (1988) Endocrine changes, with special emphasis on oestradiol$17 \beta$, prolactin and oxy tocin, before and during labour and delivery in goats. $J$. Reprod. Fert. 82, 299-308.

Flint, A.P.F., Forsling, M.L., Mitchell, M.D. \& Turnbull, A.C. (1975) Temporal relationship between changes in oxytocin and prostaglandin $\mathrm{F}$ levels in response to vaginal distension in the pregnant and puerperal ewe. J. Reprod. Fert. 43, 551-556.

Garfield, R.E., Sims, S.M., Kamen, M.S. \& Daniel, E.E. (1978) Possible role of gap junctions in activation of myometrium during pregnancy. Am. J. Physiol. 235, C168-C179.

Garfield, R.E., Kamen, M.S. \& Daniel, E.E. (1980) Gap junction formation in myometrium: control by estrogen, progesterone, and prostaglandins. Am. J. Physiol. 237, C81-C89.
Ginther, O.J. (1979) Reproductive Biology of the Mare. McNaughton \& Gunn, Inc., Ann Arbor.

Goto, M. \& Csapo, A. (1959) The effect of ovarian steroids on the membrane potential of uterine muscle. J. gen. Physiol. 43, 455-466.

Haluska, G.J., Lowe, J.E. \& Currie, W.B. (1987a) Electromyographic properties of the myometrium correlated with the endocrinology of the pre-partum and post-partum periods and parturition in pony mares. J. Reprod. Fert., Suppl. 35. 553-564.

Haluska, G.J., Lowe, J.E. \& Currie, W.B. (1987b) Electromyographic properties of the myometrium of the pony mare during pregnancy. J. Reprod. Fert. 81, $471-478$.

Ham, E.A., Cirillo, V.J., Fanetti, M.E. \& Kuehl, F.A. (1975) Estrogen directed synthesis of specific prostaglandins in the uterus. Proc. natn. Acad. Sci. U.S.A. 72, 1420-1424.

Hillman, R.B. (1975) Induction of parturition in mares. J. Reprod. Fert., Suppl. 23, 641-644.

Holtan, D.W., Nett, T.M. \& Estergreen, V.L. (1975a) Plasma progestagens in pregnant mares. J. Reprod. Fert., Suppl. 23, 419-424.

Holtan, D.W., Nett, T.M. \& Estergreen, V.L. (1975b) Plasma progestagins in pregnant, postpartum and cycling mares. J. Anim. Sci. 40, 251-260.

Howell, C.E. \& Rollins, W.C. (1951) Environmental sources of variation in the gestation length of the horse. J. Anim. Sci. 10, 789-796.

Kalin, N.H., Gibbs, D.M., Barksdale, C.M., Shelton, S.E. \& Carnes, M. (1985) Behavioral stress decreases plasma oxytocin concentrations in primates. Life. Sci. 36, 1275-1280.

Kuriyama, H. \& Csapo, A. (1961) Placental and myometrial block. Am. J. Obstet. Gynecol. 82, 592-599.

Matzke, H.A. \& Foltz, F.M. (1983) Synopsis of Neuroanatomy, 4th edn, ch. 18, p. 109. Oxford University Press, London.

Mercado-Simmen, R.C., Bryant-Greenwood, G.D. \& Greenwood, F.C. (1982) Relaxin receptors in the rat myometrium: regulation by estrogens and relaxin. Endocrinology 110, 220226.

Mitchell, M.D., Flint, A.P.F. \& Turnbull, A.C. (1975) Stimulation by oxytocin of prostaglandin $F$ levels in uterine venous effluent in pregnant and puerperal sheep. Prostaglandins 9, 47-56.

Nett, T.M., Holtan, D.W. \& Estergreen V.L. (1973) Plasma estrogens in pregnant and post partum mares. J. Anim. Sci. 37, 962-970.

Pashen, R.L. \& Allen, W.R. (1979a) The role of the fetal gonads and placenta in steroid production, maintenance of pregnancy and parturition in the mare. $J$. Reprod. Fert., Suppl. 27, 499-509.

Pashen, R.L. \& Allen, W.R. (1979b) Endocrine changes after foetal gonadectomy and during normal and induced parturition in the mare. Anim. Reprod. Sci. 2, $271-288$.

Pope, N.S., Sargent, G.F., Wiseman, B.S. \& Kesler, D.J. (1987) Transitory changes of hormones in the plasma of parturient pony mares. J. Reprod. Fert., Suppl. 35, 629-634.

Quirk, S.M. \& Currie, W.B. (1984) Uterine steroid receptor changes associated with progesterone withdrawal 
during pregnancy and pseudo-pregnancy in the rabbit. Endocrinology 114, 182-191.

Ropiha, R.T., Mathews, R.W., Betterfield, R.M., Moss, F.P. \& McFadden, W.J. (1969) The duration of pregnancy in thoroughbred mares. Vet. Rec. 84, 552-555.

Seamans, K.W., Harms, P.C., Atkins, D.T. \& Fleeger, J.L. (1979) Serum levels of progesterone, $5 \alpha$ dihydroprogesterone and hydroxy-5 $\alpha$-pregnanes in the prepartum and postpartum equine. Steroids 33, 2385-2393.

Seren, E., Tamanini, C., Gaiani, R. \& Bono, G. (1981) Concentrations of progesterone, $17 \alpha$-hydroxyprogesterone, and $20 \alpha$-dihydroprogesterone in the plasma of mares during pregnancy and at parturition. $J$. Reprod. Fert. 63, 443-448.
Silver, M., Barnes, R.J., Comline, R.S., Fowden, A.L., Clover, L. \& Mitchell M.D. (1979) Prostaglandins in maternal and fetal plasma and in allantoic fluid during the second half of gestation in the mare. $J$. Reprod. Fert., Suppl. 27, 531-539.

Stewart, D.R. \& Stabenfeldt, G.H. (1981) Relaxin activity in the pregnant mare. Biol. Reprod. 25, $281-289$.

Stewart, D.R., Kindahl, H., Stabenfeldt, G.H. \& Hughes, J.P. (1984) Concentration of 15 keto-13,14-dihydroprostaglandin $\mathrm{F}_{2 a}$ in the mare during spontaneous and oxytocin induced foaling. Equine vet. J. 16, $270-274$.

Received 13 April 1988 